\title{
Impact of electric passenger cars in India: A review
}

\section{Deepankar Sinha}

Associate Professor, Indian Institute of Foreign Trade, New Delhi, India

*Corresponding Author:

Email: dsinha2000@gmail.com

\begin{abstract}
India, like any other country, in the world is concerned about increasing air pollution arising out of $\mathrm{CO}_{2}$ emissions from use of cars and vehicles. The government has been promoting use of electric vehicles and is likely to announce a full proof policy. However, several factors such as cost of production, growing prices of battery and environmental concerns arising out of battery waste are likely to be elements that will lead to limits to growth of e-cars (electric cars or electric vehicles) in the country. In this paper, a study has been made regarding projection of growth of electric vehicles (EV) and the causes that may hinder such a growth. Results show that leading car manufacturer is apprehensive about keeping the price of car in the range affordable by the Indian customers; companies worldwide are concerned about economic viability and technical feasibility of recycling battery waste; the battery charging infrastructure and the damage that the environment is also likely to sustain due to mining of lithium and cobalt.
\end{abstract}

Keywords: Electric Vehicles, Passenger Car, Growth, Cost, Cobalt, Environment, Limits to growth.

\section{Introduction}

The Government of India recently stressed on introduction of electric cars in India. It appealed car makers to roll out electric cars in Indian roads (Saluja, 2017). The Union Minister of Road Transport indicated that a fool proof policy on the lines of "Transport for London (TfL)" will be introduced and an MOU is proposed to be signed with TfL (Vashisht, 2018). This is expected to have manifold benefits such as reduction in carbon oxide gases, reduction in crude oil imports and in turn enhance health condition of the citizens and reduce outflow of foreign reserves (through reduction in imports). Another important aspect would be also the fluctuating crude prices.

According to BCG (Boston Consulting Group, 2010), the value chain of electric battery involves seven stages. These are the production stages associated with component, cell, and module; pack - assembly, vehicle integration, use, reuse and recycling as illustrated in Fig. 1.

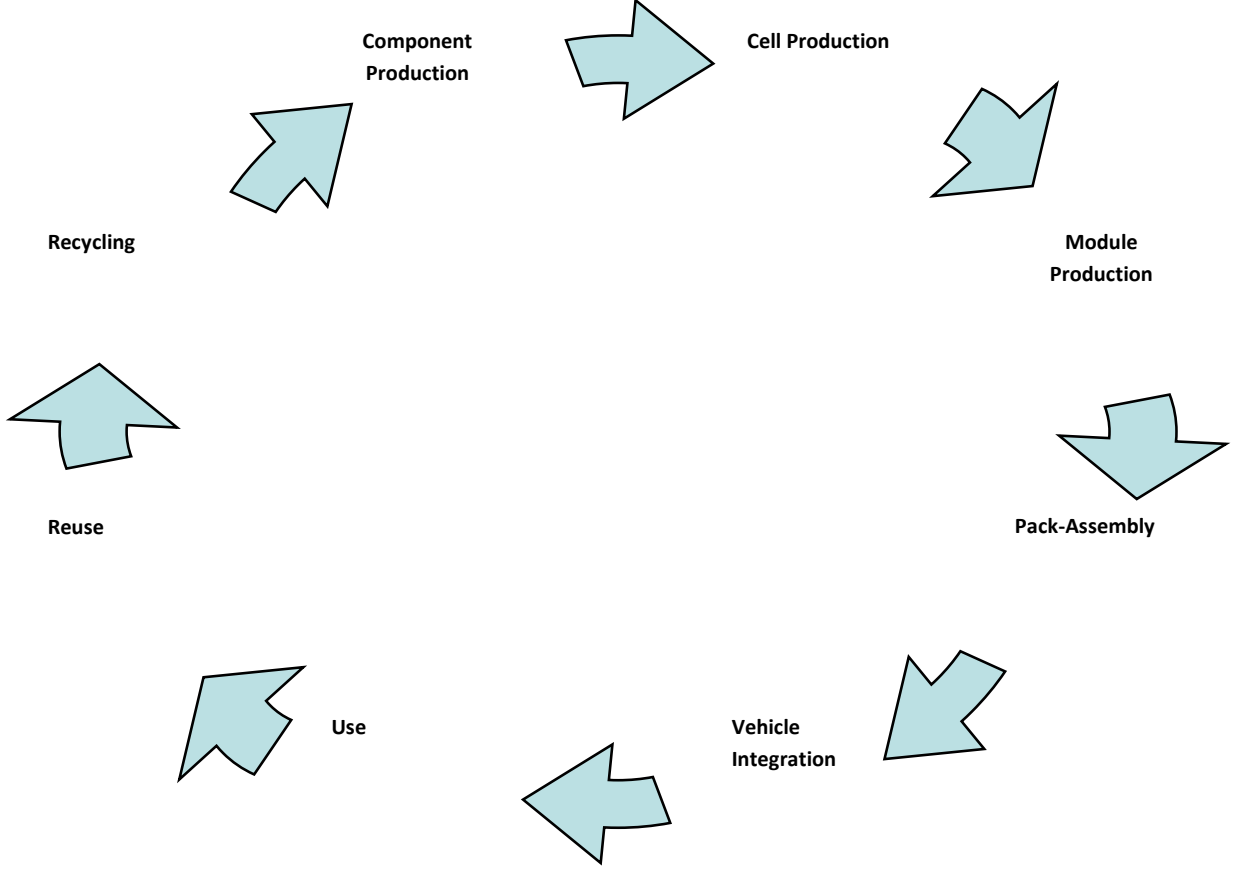

Fig. 1: Stages in Electric Car Battery Value Chain 
Each of these stages requires exclusive planning. The component production that require metals such as Lithium and Cobalt need to accessed on continuous basis. Battery producer major such as Tesla have reported to have looking for Cobalt mines (Insideevs, 2018), though the major source have been Congo. Questions have been also raised regarding the cost to human life in miming Cobalt. The mining is done using hand and is affecting lives of inhabitants of Congo (Frankel, 2016). Tesla has over 300 suppliers across the globe for their product and many these suppliers are single source of supply. Stoppage of supply may lead to supply chain disruption. The key raw materials include aluminium, steel, nickel, copper and cobalt. The company has been experiencing price fluctuations of these raw materials (CSI Market, 2017). The stages of cell and module production followed by pack assembly are dependant on plant's production capacity. The use of battery driven cars is dependent on availability charging stations, capacity of charging vehicles (that is, number of charging points per station) and time to charge per car. The government of India planned to procure electric cars through the nodal body called Energy Efficiency Services Ltd. (EESL). However the procurement process is getting delayed due to lack of infrastructure to charge the battery. The car supply will be made by companies namely, Tata motors Ltd., and Mahindra and Mahindra Limited through EEFSL. The country plans to intergrate the charging stations with the present re-fuelling stations. However, it is required to be studied the constraints in using the current refuelling pumps. This is so because all pumps are not having similar layout and can afford to provide adequate charging stations.

The reusability depends on the plant capacity to extract the costly minerals and cost of such extraction.

The report stress that the lithium ion technologies have under focus as could be seen from the increase in patents in this field. The patents increased from 26 percent in 2005 to 62 percent in 2008. The characteristics of lithium ion battery can be assessed across six dimensions. These are the safety, life span, cost, performance, energy-storage and state-of-charge measurement. Another challenge of lithium ion battery is that of charging infrastructure. Re-use and re-cycling are the areas that have not been given much thought as most of the effort is reduction of cost of car and its usability. The report stresses that the challenges for the car makers lay in bringing down the cost, increasing the driving range and cutting down the charging time. Niti Ayog, India's apex planning body opined that the country needs big plants to make electric car batteries. Industrial houses such as Reliance, Adani, JSW, the Hero Group of Companies and Mahindra and Mahindra have shown interest in setting up such plants in India (PTI, 2017). Honda, a Japanese car manufacturing company has planned to setup its own battery manufacturing plant in India. The car manufacturer aims at having 65 percent share of its production in electric cars, hybrid cars, plug-in hybrid cars and fuelcell powered cars. Out of this, 15 percent would be pure electric cars (Mukherjee, 2017).

However, there are flip sides of uncontrolled growth in use of battery for electric cars. Or rather there could be limits to growth of e-cars in India. In this paper an analysis has been made to study the impact of e-cars in India. The study aims at exploring the factors that govern the dynamics of e-car usage in India. A statistical analysis has been carried out to project the growth of electric passenger cars and its impact studied to identify the limits to growth of e-cars.

\section{Share of Passenger Cars in India}

Around 72 million passenger cars travel the roads of the world as on 2016 and India's share is around 5\% (OICA, 2018). The sales have been increasing over the years. Table 1 shows the total passenger car sales during the period 2005-2006. Figure 2 illustrates the trend in sales.

Table 1: Total passenger car sales during the period 2005-2006

\begin{tabular}{|c|c|}
\hline \multicolumn{1}{|c|}{ Year } & Sales \\
\hline 2005 & $454,07,298$ \\
\hline 2006 & $479,55,259$ \\
\hline 2007 & $508,34,531$ \\
\hline 2008 & $499,78,237$ \\
\hline 2009 & $496,54,985$ \\
\hline 2010 & $558,18,570$ \\
\hline 2011 & $578,39,953$ \\
\hline 2012 & $609,36,407$ \\
\hline 2013 & $634,29,200$ \\
\hline 2014 & $657,08,230$ \\
\hline 2015 & $663,14,155$ \\
\hline 2016 & $694,64,432$ \\
\hline
\end{tabular}

Source: http://www.oica.net/category/productionstatistics/2016-statistics/ 


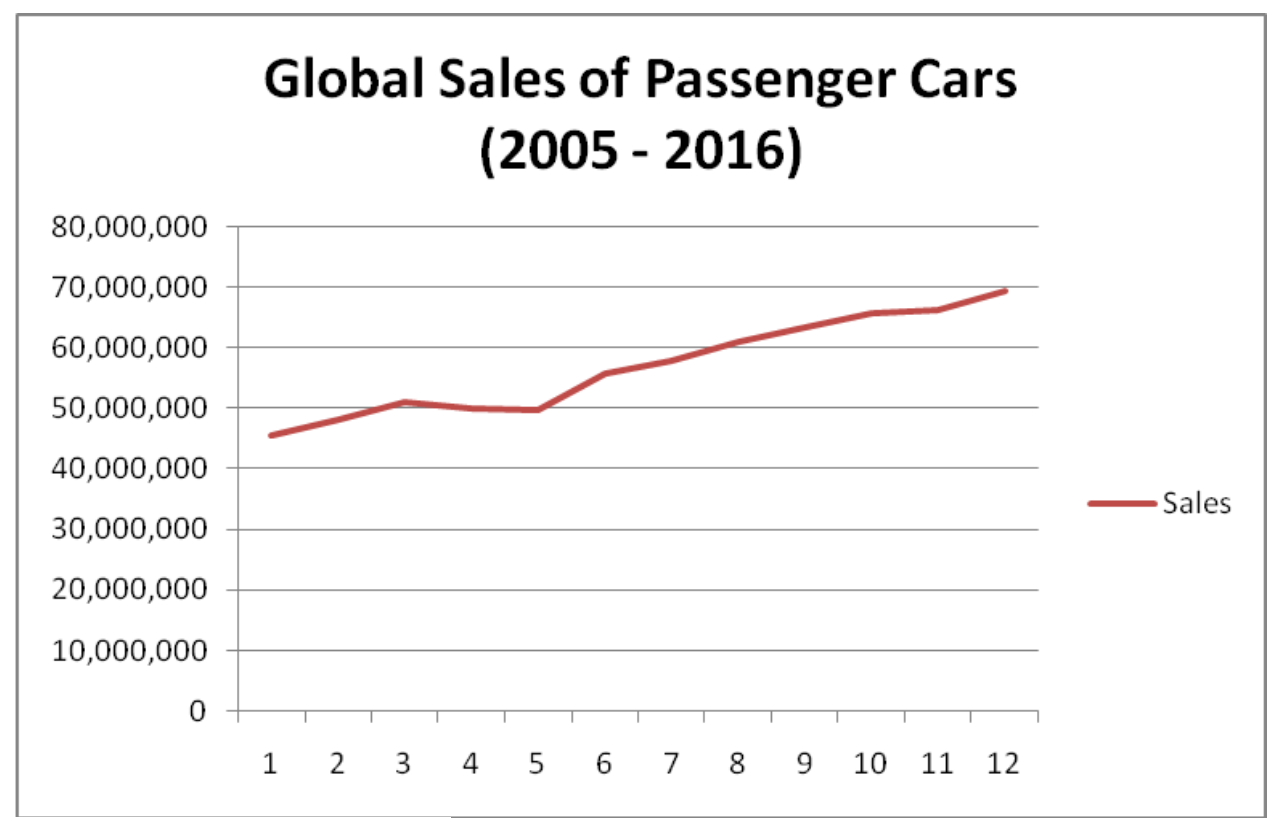

Fig. 2: Trend in global passenger car sales

The sales of passenger cars have been also growing in India (Fig. 3).

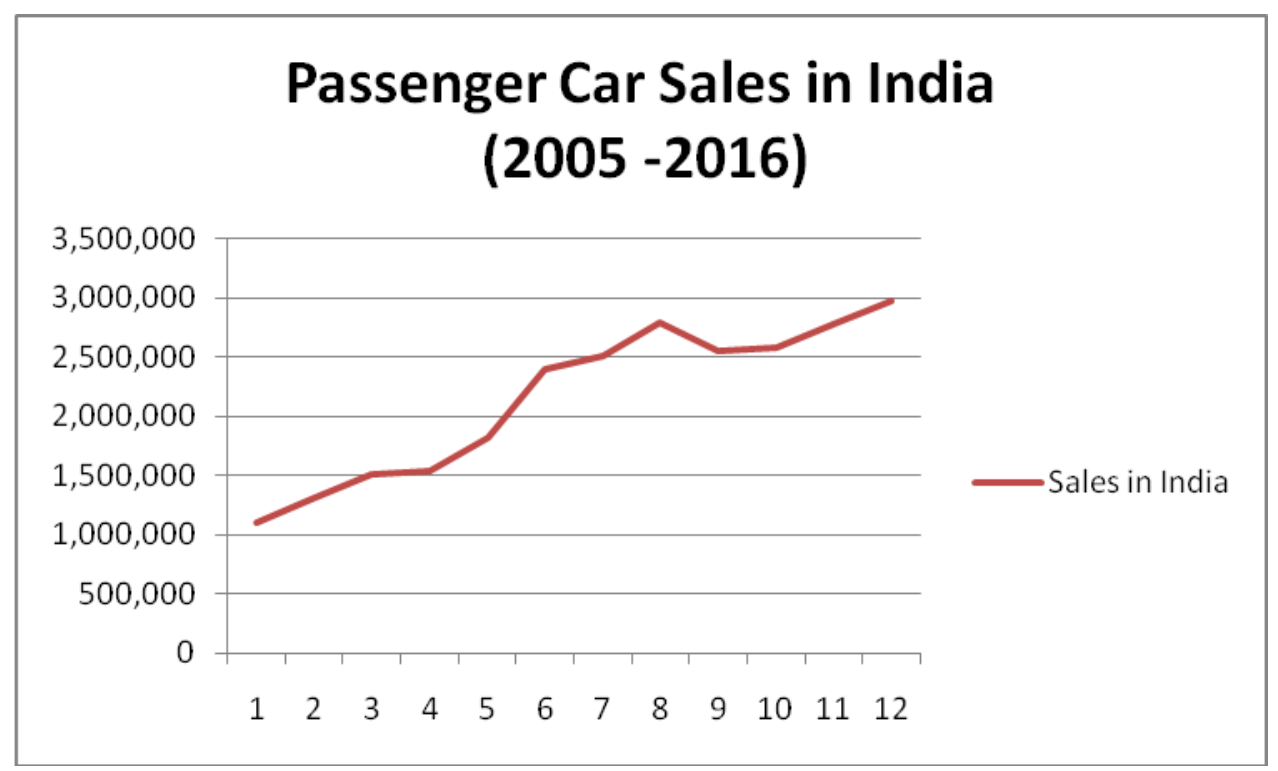

Source: http://www.oica.net/category/production-statistics/2016-statistics/

Fig. 3: Trend of passenger car sales in India

In year 2015 the $\mathrm{CO}_{2}$ emissions has been around $130 \mathrm{CO}_{2} / \mathrm{km}$ for passenger cars in Europe (Fontaras et al., 2017). The cars in India too opt for European standards. However CO2 emissions depend on several factors such as vehicle characteristics (weight, aero dynamics, auxiliary systems), vehicle driver (driving skills and style of driving), traffic condition and weather conditions (Fontaras et al., 2017). In India city roads are congested, vehicles are not properly maintained and driving skills are not consistent, hence the $\mathrm{CO} 2$ levels tend to have an increasing trend. Thus electric cars are certainly going to benefit the country.

\section{Analysis}

The below table 2 shows the sales of Passenger cars and Electric vehicles (EV) from 2005 to 2016 
Table 2: Sale of Electric Vehicle

\begin{tabular}{|c|c|c|c|}
\hline Year & Global EV Sales & $\begin{array}{c}\text { Global Car } \\
\text { Sales }\end{array}$ & $\begin{array}{c}\text { \% Share of } \\
\text { EV }\end{array}$ \\
\hline 2005 & 1890 & $4,54,07,298$ & 0.004162327 \\
\hline 2006 & 320 & $4,79,55,259$ & 0.000667289 \\
\hline 2007 & 460 & $5,08,34,531$ & 0.000904897 \\
\hline 2008 & 2460 & $4,99,78,237$ & 0.004922142 \\
\hline 2009 & 2220 & $4,96,54,985$ & 0.00447085 \\
\hline 2010 & 6780 & $5,58,18,570$ & 0.012146495 \\
\hline 2011 & 47580 & $5,78,39,953$ & 0.082261478 \\
\hline 2012 & 118060 & $6,09,36,407$ & 0.193742962 \\
\hline 2013 & 203660 & $6,34,29,200$ & 0.321082404 \\
\hline 2014 & 323420 & $6,57,08,230$ & 0.492206227 \\
\hline 2015 & 547120 & $6,63,14,155$ & 0.825042557 \\
\hline 2016 & 753170 & $6,94,64,432$ & 1.084252733 \\
\hline
\end{tabular}

Source: Bloomberg: https://about.bnef.com/electric-vehicle-outlook/

The trend of global sales of car is as shown below (Fig. 4). The car sales show a linear rising trend.

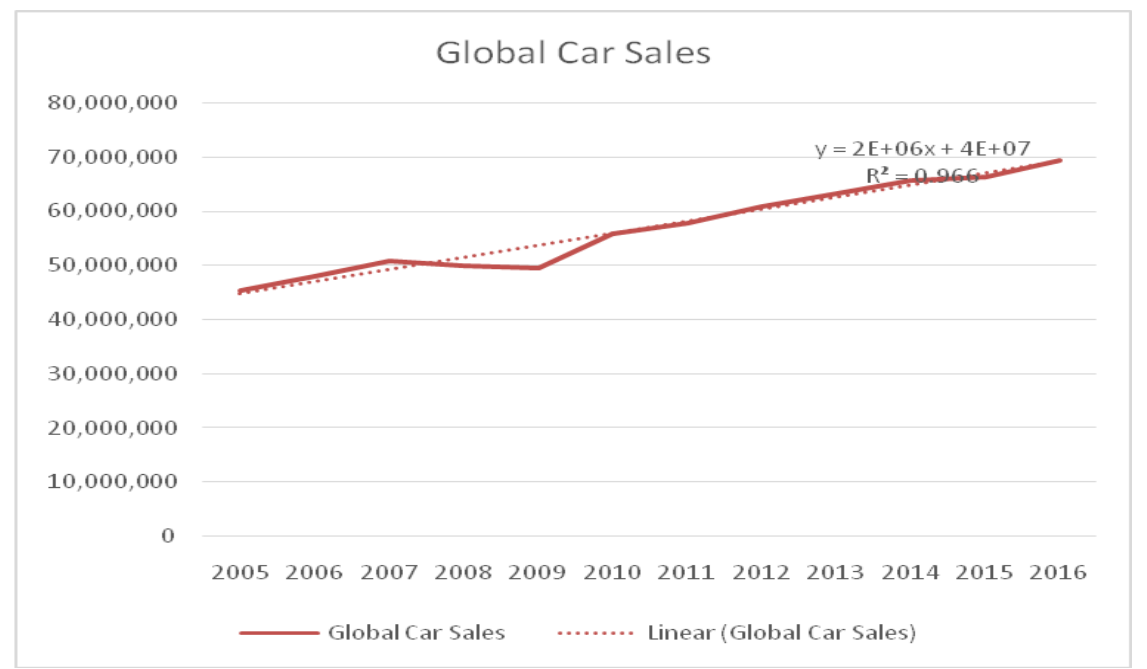

Fig. 4: The sales trend with the trend line equation

The trend of global electric vehicle sales along with trend equation is given below (Fig. 5). The sales have gone up exponentially since 2011 . 


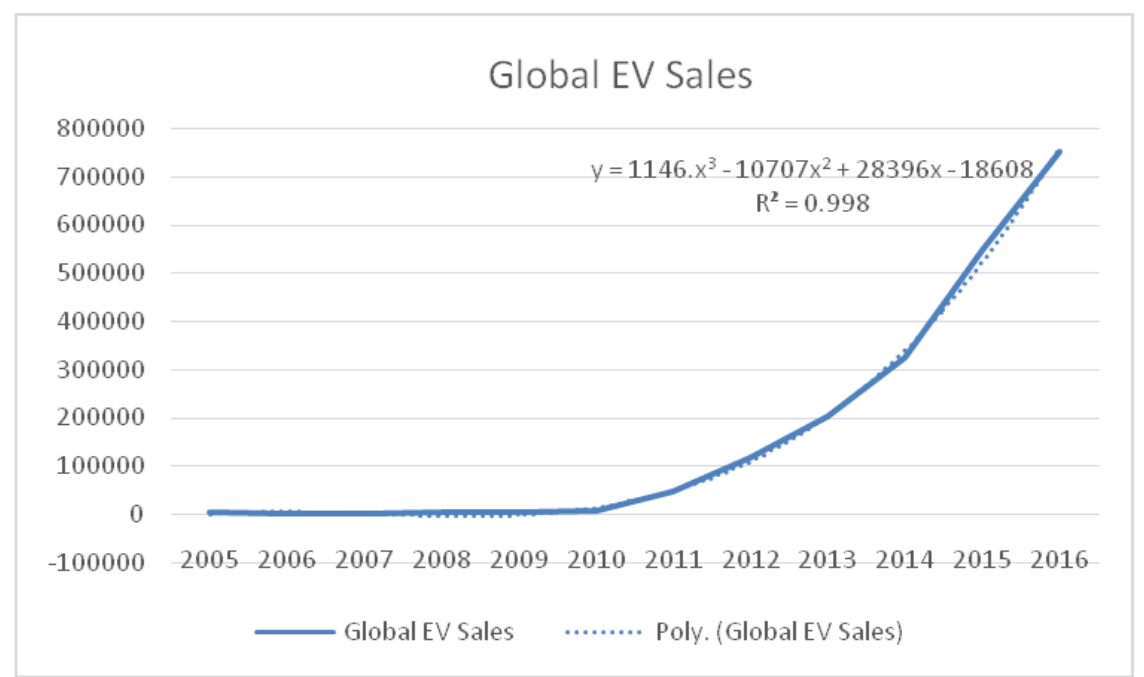

Fig. 5: Global sales trend=d of electric vehicles $(\mathrm{EV})$

By analyzing the past trends, we have attempted to project the sales of both EVs and the total passenger cars and the numbers is as given in the below (table3).

Table 3: Projection of Electric Vehicle sales

\begin{tabular}{|c|c|c|c|}
\hline Year & $\begin{array}{c}\text { Projected Global } \\
\text { Car Sales }\end{array}$ & EV Projected & $\begin{array}{c}\text { \% Projected Share } \\
\text { of EV }\end{array}$ \\
\hline 2005 & 44693279.88 & 227.5 & 0.000509025 \\
\hline 2006 & 46920884.39 & 4528 & 0.009650287 \\
\hline 2007 & 49148488.91 & 1172.5 & 0.002385628 \\
\hline 2008 & 51376093.43 & -2960 & -0.005761435 \\
\hline 2009 & 53603697.95 & -990.5 & -0.00184782 \\
\hline 2010 & 55831302.47 & 13960 & 0.025003895 \\
\hline 2011 & 58058906.99 & 48770.5 & 0.084001754 \\
\hline 2012 & 60286511.51 & 110320 & 0.182992841 \\
\hline 2013 & 62514116.03 & 205487.5 & 0.32870576 \\
\hline 2014 & 64741720.55 & 341152 & 0.526943055 \\
\hline 2015 & 66969325.07 & 524192.5 & 0.782735229 \\
\hline 2016 & 69196929.59 & 761488 & 1.100465013 \\
\hline 2017 & 71424534.11 & 1059917.5 & 1.483968378 \\
\hline 2018 & 73652138.62 & 1426360 & 1.936617221 \\
\hline 2019 & 75879743.14 & 1867694.5 & 2.461387483 \\
\hline 2020 & 78107347.66 & 2390800 & 3.060915614 \\
\hline 2021 & 80334952.18 & 3002555.5 & 3.737545637 \\
\hline 2022 & 82562556.7 & 3709840 & 4.493368602 \\
\hline 2023 & 84790161.22 & 4519532.5 & 5.330255816 \\
\hline 2024 & 87017765.74 & 5438512 & 6.249886967 \\
\hline 2025 & 89245370.26 & 6473657.5 & 7.25377404 \\
\hline 2026 & 91472974.78 & 7631848 & 8.343281738 \\
\hline 2027 & 93700579.3 & 8919962.5 & 9.519644987 \\
\hline 2028 & 95928183.82 & 10344880 & 10.78398401 \\
\hline 2029 & 98155788.33 & 11913479.5 & 12.13731732 \\
\hline 2030 & 100383392.9 & 13632640 & 13.58057305 \\
\hline 2031 & 102610997.4 & 15509240.5 & 15.11459872 \\
\hline 2032 & 104838601.9 & 17550160 & 16.74016983 \\
\hline 2033 & 107066206.4 & 19762277.5 & 18.45799731 \\
\hline 2034 & 109293810.9 & 22152472 & 20.26873417 \\
\hline 2035 & 111521415.4 & 24727622.5 & 22.17298122 \\
\hline 2036 & 113749020 & 27494608 & 24.17129221 \\
\hline 2037 & 115976624.5 & 30460307.5 & 26.26417835 \\
\hline
\end{tabular}




\begin{tabular}{|l|c|c|c|}
\hline 2038 & 118204229 & 33631600 & 28.45211232 \\
\hline 2039 & 120431833.5 & 37015364.5 & 30.73553181 \\
\hline 2040 & 122659438 & 40618480 & 33.11484273 \\
\hline
\end{tabular}

Source: Bloomberg-https://about.bnef.com/electric-vehicle-outlook/

This was done using the TREND Function for passenger cars as it followed a linear trend of growth during 2005-2016 while Polynomial regression of order 3 was employed to project EV sales till 2040. It must be noted that this is a pure statistical projections without considering the factors like falling prices of lithium ion batteries, government subsidies etc. The trend shows increase in years ahead as it has been based on past trends. However past trend may not be repeated as there are limitations with regard to sourcing of raw materials, production capacity, charging infrastructure, recycling and environmental concerns. Government may soon announce policy regarding recycling and disposal of used battery.

Graph 1: Emerging Technologies: Battery storage 2012 cost projections for 2030 have already happened: Long term implications on
renewables, transport electrification

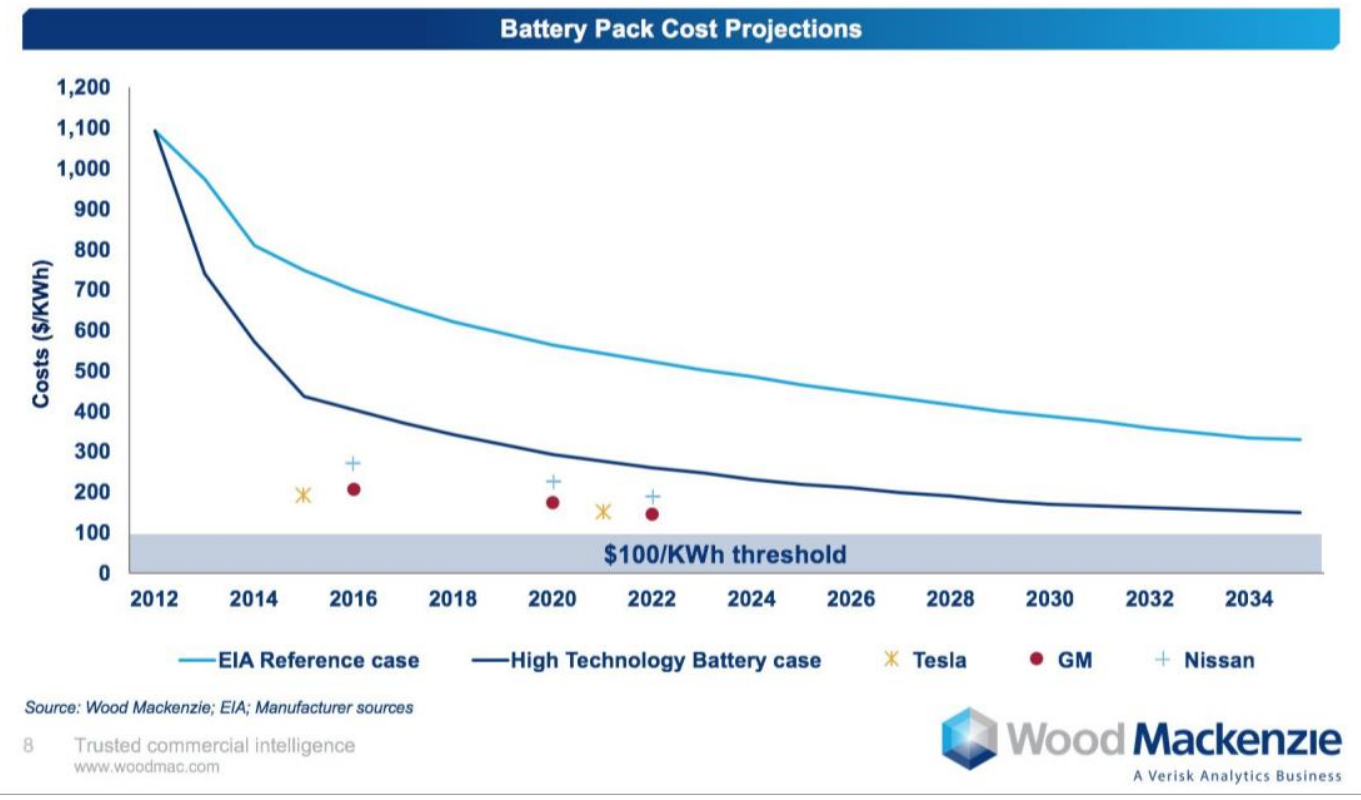

The above projection shows decrease in cost of battery pack, however, on need to consider the doubling of cost of cobalt over past one year.

\section{Results and Conclusion}

It is projected that in 2040 the share of EV will be $33.11 \%$ of total passenger car sales. This goes in line with the projections of various agencies such as Bloomberg who predicted around 35\% to $54 \%$ share of EVs in 2040 (Bloomberg, 2017).

The vehicles with Internal Combustion Engines which constitute more than $98 \%$ of the share would be reduced to $66 \%$ or even lesser in the wake of new innovative and sustainable technologies.

This would mean that dependence on crude oil would reduce greatly and would go a long way in the sustaining the environment for future generations. Besides, the cost of lithium ion batteries are likely to drop by $70 \%$ by 2030 (Bloomberg, 2017). However Bloomberg (2017 b) also reported that the price of lithium and cobalt have doubled over the last one year. It prescribes mining batteries is much profitable than mining ground for the metals. Companies, such as Tesla and Toyota Motor Corp., are considering 10\% recycling of the battery. Thus price of cobalt will be key to growth of electric cars (Douglas, 2017). India is a price sensitive market and hence increase in price of cars is likely to dither the customers and may lead to drop in 
drop in electric cars. Maruti Suzuki, India's leading car manufacturer apprehends its inability to keep the price of car in the affordable range of Indian customers (0.5 to 0.6 million INR) (Doval, 2018,). Besides there are environmental concerns ( Gardiner, 2018) with regard to lithium battery waste. It is estimated that the boom of e-car sales will leave around 11 million tonnes of spent lithium batteries to get recycled. The lithium ion batteries are expected to produce toxic gases when damaged and in addition mining of cobalt and lithium, being finite in availability, will lead to water pollution and other environmental consequences. The problem is aggravated with the fact that the cost of fully recycling a battery is falling toward $€ 1$ per kilo, the value of the raw materials that can be reclaimed is only a third of that (The Guardian, 2017).

The government of India apart from announcing its policy on use of electric cars, should also consider laying down guidelines for import of raw materials, reusability, recycling and disposal of used battery. It should identify the extent of such cars that can be registered keeping in mind the infrastructure available for charging and the ways and means to dispose of old fuel cars.

The car and battery industry on the other hand should invest in research and development to find out substitute of lithium and cobalt. A global convention may be held to prevent monopoly of holding rights, in hands of few manufacturers or suppliers, to mine scarce metals such as cobalt. At the same time the companies should adopt right practices avoiding child labour, illegal mining, resorting to right medical and health practices and compensating duly to the mine workers.

All these will make the industry sustainable but is likely to raise the coast atleast in the short and midterm.

\section{Scope for future research}

A multiple regression can be carried out on factors affecting the rapid rise in sales of EVs such as battery prices, Government subsidies, availability or capacity of charging stations and other factors identified in this study. The impact on the environment as a bad output may also be considered for further analysis.

\section{References}

1. BCG (Boston Consulting Group), (2010), Batteries for Electric Cars - Challenges, Opportunities and the Outlook to 2020 , https://www.bcg.com/documents/file36615.pdf

2. Bloomberg (2017b), electric Vehicle Outlook 2017, https://www.bloomberg.com/news/articles/2017-1201/the-cobalt-crunch-for-electric-cars-could-be-solved-insuburbia
3. CSIMarket, (2017), Tesla's Comment on Supply Chain, https://csimarket.com/stocks/suppliers_glance.php?code= TSLA

4. Douglas A. McIntyreNovember 23, 2017 6:30 am EST, Cobalt Price May Be Key to Electric Vehicle Growth, 247WallSt, https://247wallst.com/autos/2017/11/23/cobalt-pricemay-be-key-to-electric-vehicle-growth/

5. Doval|, Pankaj., TNN | Jan 30, 2018, 07:17 IST, Tough to price e-cars affordably: Maruti https://timesofindia.indiatimes.com/business/indiabusiness/tough-to-price-e-cars-affordablymaruti/articleshow/62703507.cms?TOI_browsernotificati on=true

6. Fontaras, Georgios., Zacharof, Nikiforos-Georgios., Ciuffo, Biagio., Fuel consumption and $\mathrm{CO}_{2}$ emissions from passenger cars in Europe - Laboratory versus realworld emissions, Progress in Energy and Combustion Science, Volume 60, May 2017, Pages 97-131

7. Frankel, Todd C., (2016), THE COBALT PIPELINE, Washinton Post, Tracing the path from deadly hand-dug mines in Congo to consumers' phones and laptops, https://www.washingtonpost.com/graphics/business/batte ries/congo-cobalt-mining-for-lithium-ion-battery/

8. Gardiner, Joey, Last modified on Thu 4 Jan 201811.03 GMT, The rise of electric cars could leave us with a big battery waste problem, https://www.theguardian.com/sustainablebusiness/2017/aug/10/electric-cars-big-battery-wasteproblem-lithium-recycling

9. Ghosh, M., (2018), Lack of charging infrastructure delays India's first electric vehicle procurement plan, http://www.livemint.com/Industry/PzKkZ41n6UHofIX15 FwAXL/Lack-of-charging-infrastructure-delays-Indiasfirst-electri.html

10. Insideevs (2018), Tesla has found yet another safe haven for Cobalt, https://insideevs.com/tesla-safe-haven-cobaltmining/

11. Mukherjee, S., (2017), Electric vehicles this week, Honda to set EV Battery Plant in India, https://inc42.com/buzz/electric-vehicles-ev-hondabattery/

12. OICA, (2017), http://www.oica.net/category/productionstatistics/2016-statistics/

13. PTI, New Delhi, October 08, 2017 16:01 IST, India needs large lithium-ion battery plants for EVs push:Niti Ayog

14. Saluja, Nishtha.,Nov 06, 2017, 11.10 PM IST, Govt working on policy to promote electric vehicles manufacturing, , ET Bureau,

https://economictimes.indiatimes.com/industry/auto/news /govt-working-on-policy-to-promote-electric-vehiclesmanufacturing/articleshow/61536316.cms

15. Vashisht, Nikita.,Feb 12, 2018 04:28 PM IST| Source: Moneycontrol.com, Policy for electric vehicles likely to follow Transport for London model, http://www.moneycontrol.com/news/business/economy/p olicy-for-electric-vehicles-likely-to-follow-transport-forlondon-model-2506109.html 